\title{
Construction Waste: Quantification and Source Evaluation
}

\author{
By B. A. G. Bossink ${ }^{1}$ and H. J. H. Brouwers ${ }^{2}$
}

\begin{abstract}
A significant part of waste generation is caused by the building and construction industry. Reduction of construction waste is therefore a major topic of the integrated chain management policy of the Dutch government. Construction companies benefit from reduced waste generation by lower deposition costs and lower purchasing costs of virgin materials. An overview is presented of the main policy areas of the Dutch government concerning sustainability. Reducing the generation of construction waste fits into this policy. Subsequently, an overview is presented from construction-waste data available in literature. Then, the waste generation during several Dutch residential construction projects has been quantified and analyzed in detail. It follows that about $1-10 \%$ by weight of the purchased construction materials, depending on the material, leave the site as waste. Furthermore, the analyses identify additional sources of waste generation as those already known, such as a lack of attention paid to the sizes of the used products, lack of influence of contractors, and lack of knowledge about construction during design activities.
\end{abstract}

\section{INTRODUCTION}

The conclusions of the World Commission on Environment and Development (Brundtland 1987) have formed the basis for the environmental strategy as advocated by the Dutch government in three successive policy documents: The Dutch $\mathrm{Na}$ tional Environmental Policy Plan (NEPP) (The Dutch National 1989); The Dutch National Environmental Policy Plan + (NEPP+) (The Dutch National 1990); and The Dutch National Environmental Policy Plan 2 (NEPP2) (The Dutch National 1993). NEPP, NEPP+, and NEPP2 describe the strategy, objectives, and measures to be taken by the government to ensure a sustainable development of Dutch society. NEPP+ also contains an appendix on sustainable construction that specifies the overall policy for the construction industry.

Sustainable development is only deemed possible when not only the government but also all other sectors of society contribute to this goal (The Dutch National 1989). The NEPPs therefore advocate a target-group approach for the implementation of the environmental policy, and pay particular attention to priority groups. The construction industry is seen as one industry where environmentally sound results should be achieved within the three central policy areas of the NEPPs: integrated chain management; energy saving; and quality improvement.

This paper focuses on prevention of the generation of construction waste. Prevention on site is an important issue in the integrated chain management policy in the sustainable-construction appendix of the NEPP+ (The Dutch National 1990). Integrated chain management in the construction industry involves closing the cycles of resource use to the greatest possible extent. The objectives are:

- Reducing the use of nonrenewable materials.

- Providing incentives for the use of renewable resources and secondary resources. Secondary resources are, for example, materials reclaimed after construction and demolition (C\&D) waste; these can be used as raw materials for the production of new building materials.

The policy also involves: preventing waste and stimulating

${ }^{1}$ Res. Fellow, Dept. of Civ. Engrg. and Mgmt., Univ. of Twente, P.O. Box 217, 7500 AE Enschede, The Netherlands.

${ }^{2}$ Assoc. Prof., Dept. of Civ. Engrg. and Mgmt., Univ. of Twente, Enschede, The Netherlands.

Note. Discussion open until August 1, 1996. To extend the closing date one month, a written request must be filed with the ASCE Manager of Journals. The manuscript for this paper was submitted for review and possible publication on May 30,1995. This paper is part of the Journal of Construction Engineering and Management, Vol. 122, No. 1, March, 1996. CASCE, ISSN 0733-9364/96/0001-0055-0060/\$4.00 + \$.50 per page. Paper No. 10827. the reclamation of construction and demolition waste, which entails a reduction in the volume of waste produced during building activities, the separation of waste materials, and a twofold increase in the use of C\&D waste; and reducing pollutive emissions into the environment during the production of building materials and the construction production process. The latter aspect means paying attention to the environmental impact of building materials and building products, and controlling the production techniques that create harmful substances at all stages of the building process.

In terms of sustainability, the topic of prevention of the generation of construction waste can be considered an issue that focuses on the danger of depletion of materials used in the construction industry, such as timber, sand, gravel, and marl. The topic also deals with the danger of contamination of the ground because it is still common practice to transport oftencontaminated construction waste to landfills. In this paper further attention is drawn to this topic. The following section contains a review on literature. In this review absolute and relative amounts of construction waste found in studies in several countries are presented to establish the size of the construction-waste issue and establish a framework to compare the results of a study conducted in The Netherlands. On the basis of the literature study and Dutch waste study, possible options are created to reduce the generation of construction waste.

\section{LITERATURE REVIEW}

The amounts of generated C\&D waste are substantial. The absolute annual amount of C\&D waste in The Netherlands is $14,000,000 \mathrm{t}$ (Implementatieplan 1993) and the share of this industry in the total amount of waste produced is $26 \%$ (Lanting 1993). This percentage agrees with the results of several studies in other countries. Craven et al. (1994) for instance, mention that $C \& D$ activity is likely to generate approximately $20-30 \%$ of all waste entering Australia's landfills; this conclusion is based on the results of three studies at several landfill sites in Melbourne and Perth. Mincks (1994) mentions that a percentage of $20 \%$ of the solid-waste stream in the United States consists of C\&D waste. This percentage is also in agreement with the value of $23 \%$ found by Apotheker (1990) and $24 \%$ by Peng et al. (1994). Rogoff and Williams (1994) reported an even higher amount of $29 \%$. On the other hand, smaller percentages were found in Germany and Finland. From Germany a percentage of $19 \%$ is reported (Brooks et al. 1994); and C\&D waste forms $13-15 \%$ of the waste disposed of at the landfill in the Helsinki, Finland, metropolitan area (Heino 1994). The data are summarized in Table 1.

The presented percentages include both construction and demolition waste. Figures show that construction waste has 
TABLE 1. C\&D Waste as Percentage of All Solld Waste Entering Landfills In Varlous Countries

\begin{tabular}{l|c}
\hline \multicolumn{1}{c|}{$\begin{array}{c}\text { Country } \\
(1)\end{array}$} & C\&D waste (by weight) \\
& $(\%)$ \\
The Netherlands & $(2)$ \\
Australia & 26 \\
United States & $20-30$ \\
Germany & $20,23,24,29$ \\
Finland & 19 \\
\hline \hline
\end{tabular}

less volume than demolition waste. The following annual volumes of C\&D waste were estimated for Germany [Hanish et al. (1991), cited in Brooks et al. (1994)]: demolition waste, $22,600,000 \mathrm{t}$; and construction waste, $10,000,000 \mathrm{t}$. Two years later, the volumes of $\mathrm{C} \& \mathrm{D}$ waste in Germany found by Kohler and Kircher (1993) [cited in Ruch and Rentz (1994)] were: demolition waste, $30,000,000 \mathrm{t}$; and waste from construction sites, $14,000,000 \mathrm{t}$.

In Western Europe, it is expected that the total amount of C\&D waste generation will reach $215,000,000 t$ in 2000 , with about $175,000,000 \mathrm{t}$ coming from demolition work and $40,000,000 \mathrm{t}$ from construction [Buchner and Scholten (1992), cited in de Pauw et al. (1994)]. These figures indicate that the weight of the generated demolition waste is more than twice the weight of the generated construction waste.

Though it seems that construction waste makes a smaller contribution to the generation of C\&D waste than demolition waste, this paper focuses on construction waste. Construction waste is an important topic to quantify and analyze despite the lower volumes in comparison with demolition waste, because:

- Construction waste is more difficult to recycle due to high levels of contamination and a large degree of heterogeneity (Brooks et al. 1994).

- Prevention of construction waste is preferable to recycling of demolition waste "at the end of the pipeline."

- Construction waste contains a relative big amount of chemical waste (Lanting 1993).

- A cost reduction caused by preventing the generation of construction waste is of direct benefit for most of the participants that work on a construction project.

Some studies have been conducted in Brazil to determine the waste rates for construction materials on site. According to Pinto and Agopayan (1994), experimental studies pointed out that the waste rate in the Brazilian construction industry is as high as $20-30 \%$ of the weight of total materials on site. Hamassaki and Neto (1994) conclude on the basis of research in the south region of Brazil that $25 \%$ of construction materials are wasted during the construction operations. Finally, Formoso et al. (1993) [cited in Craven et al. (1994)] estimated the amount of construction waste generated in Brazil to be as much as $20 \%$ of all materials delivered to site. The data are listed in Table 2.

Waste can occur at any stage because of not only construction activities but also external factors such as theft and vandalism. These external influences are likely to influence the statistics on construction waste. It is not clear whether the reported amounts account for these external factors. A second critical note is that the waste rates in Brazil may not be directly comparable to those from other countries in consequence of differences in used construction techniques, work procedures, and common practices. At any rate, Table 2 indicates that the amount of construction materials wasted on site cannot be neglected. Soibelman et al. (1994) state, for example, that the real average loss of material has a big variation interval, and is located between 0.85 and eight times the usual admitted
TABLE 2. Construction Waste as Percentage of Total Amount of Purchased Construction Material in Brazil

\begin{tabular}{l|c}
\hline \hline \multicolumn{1}{c|}{$\begin{array}{c}\text { Reference } \\
(1)\end{array}$} & $\begin{array}{c}\text { Construction waste (by weight) } \\
(\%)\end{array}$ \\
\hline $\begin{array}{l}\text { Pinto and Agopayan (1994) } \\
\text { Hamassaki and Neto (1994) }\end{array}$ \\
$\begin{array}{l}\text { Formoso et al. (1993) [cited in Cra- } \\
\text { ven et al. (1994)] }\end{array}$ \\
\hline \hline
\end{tabular}

TABLE 3. Construction Waste of Specific Material as Percentage of Total Purchased Amount of Specific Conetruction Material in Brazil (by Woight)

\begin{tabular}{|c|c|c|c|}
\hline $\begin{array}{l}\text { Construction } \\
\text { material } \\
(1) \\
\end{array}$ & $\begin{array}{c}\text { Pinto } \\
\text { (1989) } \\
(2) \\
\end{array}$ & $\begin{array}{c}\text { Solbelman } \\
\text { ot al. (1994) } \\
\text { (3) }\end{array}$ & $\begin{array}{c}\text { Pinto and Agopayan } \\
(1994) \\
(4)\end{array}$ \\
\hline $\begin{array}{l}\text { Steel } \\
\text { Cement } \\
\text { Concrete } \\
\text { Sand } \\
\text { Mortar } \\
\text { Ceramic block } \\
\text { Brick } \\
\text { Timber } \\
\text { Hydrated lime } \\
\text { Wall ceramic tile } \\
\text { Floor ceramic tile }\end{array}$ & $\begin{array}{r}21 \% \\
25 \% \\
1 \% \\
28 \% \\
50 \% \\
- \\
11 \% \\
- \\
- \\
-\end{array}$ & $\begin{array}{l}16 \% \\
46 \% \\
12 \% \\
31 \% \\
48 \% \\
21 \% \\
23 \% \\
- \\
- \\
-\end{array}$ & $\begin{array}{r}26 \% \\
33 \% \\
2 \% \\
28 \% \\
46 \% \\
\overline{12 \%} \\
32 \% \\
51 \% \\
9 \% \\
7 \%\end{array}$ \\
\hline
\end{tabular}

TABLE 4. Sources and Causes of Construction Waste (Gavilan and Bernold 1994; Craven ot al. 1994)

\begin{tabular}{|c|c|}
\hline $\begin{array}{l}\text { Source } \\
\text { (1) }\end{array}$ & $\begin{array}{c}\text { Cause } \\
\text { (2) }\end{array}$ \\
\hline $\begin{array}{l}\text { Design } \\
\text { Design }\end{array}$ & $\begin{array}{l}\text { Error in contract documents } \\
\text { Contract documents incomplete at commencement of } \\
\text { construction }\end{array}$ \\
\hline $\begin{array}{l}\text { Design } \\
\text { Procurement }\end{array}$ & $\begin{array}{l}\text { Changes to design } \\
\text { Ordering error, overordering, underordering, and so } \\
\text { on }\end{array}$ \\
\hline Procurement & Suppliers error \\
\hline Materials handling & Damaged during transportation to site/on site \\
\hline Materials handling & $\begin{array}{l}\text { Inappropriate storage leading to damage or deterior- } \\
\text { ization }\end{array}$ \\
\hline Operation & Error by tradesperson or laborer \\
\hline Operation & Equipment malfunction \\
\hline Operation & Inclement weather \\
\hline Operation & Accidents \\
\hline Operation & Damage caused by subsequent trades \\
\hline Operation & Use of incorrect material requiring replacement \\
\hline Residual & Conversion waste from cutting uneconomical shapes \\
\hline Residual & Offcuts from cutting materials to length \\
\hline Residual & $\begin{array}{l}\text { Overmixing of materials for wet trades due to a lack } \\
\text { of knowledge of requirements }\end{array}$ \\
\hline Residual & Waste from application process \\
\hline Residual & Packaging \\
\hline Other & Criminal waste due to damage or theft \\
\hline Other & $\begin{array}{l}\text { Lack of on site materials control and waste manage- } \\
\text { ment plans }\end{array}$ \\
\hline
\end{tabular}

waste. Although some residual level of construction waste seems unavoidable, the potential cost reduction by preventing generation of construction waste on site is substantial and can be an incentive for participants in construction projects to put efforts in minimizing construction waste.

To gain insight in the percentages of generated waste during construction operations for specific materials, results of three studies in Brazil are listed in Table 3. The table contains the results of a study by Pinto (1989, cited in Soibelman et al. 1994), a synthesis of the results obtained in five construction sites researched by Soibelman et al. (1994) and the results of experimental studies described by Pinto and Agopayan (1994).

Table 3 shows that there is an enormous variation in waste 
percentages between different construction materials in a study. Pinto (1989) [cited in Soibelman et al. 1994], for example, found a waste percentage of $1 \%$ for concrete and $50 \%$ for mortar. Table 3 also shows that the differences of waste percentages for a specific construction material between the three studies in most cases are small. For instance, Pinto (1989) [cited in Soibelman et al. 1994] and Pinto and Agopayan (1994) found a waste percentage for sand equal to $28 \%$; Soibelman et al. (1994), a percentage of $31 \%$. These percentages agree with each other to a fairly high degree.

To be able to reduce the amount of construction waste, the question occurs as to what the main causes of the generation are. Table 4 lists the main causes of construction waste found by Gavilan and Bernold (1994) and Craven et al. (1994).

The last participant to be involved in any building project, the contractor, is confronted with the positive and the negative environmental effects of a lot of the activities of the previous stages of the project. But reduction of construction waste is not only a responsibility of the construction company. The client and designer, as Table 4 indicates, can make environment-friendly choices in the program of demands and the design. The awareness that client, designer, and contractor are able to reduce the amount of generated construction waste during a construction project was the starting point of a research project in The Netherlands.

\section{CONSTRUCTION WASTE IN DUTCH CONSTRUCTION INDUSTRY}

In this section the results of a research project, conducted in The Netherlands (Bossink 1994; Ottens 1994; Preventie 1994), will be presented. The research was conducted from April 1993 to June 1994. In cooperation with the building contractor, the amount of construction waste was measured at the building sites of five housing construction projects. The first project involved eight single-family homes; the second, six single-family homes; the third, 136 senior-citizens' apartments; the fourth, 16 single-family homes; and the fifth, 18 single-family homes. The next step was determining what caused the various kinds of construction waste, again in cooperation with the building contractor.

During the study all construction waste materials were sorted and weighed. The result was a complete inventory of the amounts of the various waste fractions. The sorting was done in accordance with the use made of a particular building material. The subsequent weighing resulted in the statistics shown in Table 5, which indicates that the largest source of construction waste is the use of stone tablets $(29 \%)$. The use of piles $(17 \%)$, concrete (13\%), sand-lime elements $(11 \%)$, and roof tiles $(10 \%)$ also contributed greatly to the total amount of construction waste in these building projects. Together, stone tablets, piles, concrete, sand-lime elements, and roof tiles account for $80 \%$ of the total amount of waste.

In Table 6 the amount of waste (percentage by weight) for each building material is compared with the amounts of material purchased. Table 6 shows that the amount of waste for each building material lies between $1 \%$ and $10 \%$ of the amount purchased. The average amount of the purchased construction materials that end up as construction waste is $9 \%$ (by weight). A reduction of the amount of construction waste would therefore lead to substantial savings on the purchasing costs of building materials, in addition to savings on dumping costs.

Finally, Table 7 shows what percentage of the total waste costs (purchasing costs plus transport costs plus waste-management costs) is caused by the use of a particular building material. This table also presents the average results of the five building projects.

It appears that the various participants in the building process (client, designer, supplier, and building contractor) are
TABLE 5. Construction Waste of Fractions as Percentage of Total Amount of Construction Waste

\begin{tabular}{|c|c|}
\hline $\begin{array}{l}\text { Application of construction material } \\
\text { (1) }\end{array}$ & $\begin{array}{c}\text { Construction } \\
\text { waste (by weight) } \\
(\%) \\
(2) \\
\end{array}$ \\
\hline $\begin{array}{l}\text { Stone tablets } \\
\text { Piles } \\
\text { Concrete } \\
\text { Sand-lime elements } \\
\text { Roof-tiles } \\
\text { Mortar } \\
\text { Packing } \\
\text { Sand-lime bricks } \\
\text { Remainder (mainly small fractions of metal and } \\
\text { wood) }\end{array}$ & $\begin{array}{r}29 \\
17 \\
13 \\
11 \\
10 \\
8 \\
7 \\
3 \\
2\end{array}$ \\
\hline
\end{tabular}

TABLE 6. Construction Waste of Fraction as Percentage of Purchased Amount of Speciflc Constructlon Material

\begin{tabular}{l|c}
\hline \multicolumn{1}{c|}{ Application of construction material } & $\begin{array}{c}\text { Construction } \\
\text { wasto (by weight) } \\
(1)\end{array}$ \\
\hline Stone tablets & $(2)$ \\
Piles & 9 \\
Concrete & 5 \\
Sand-lime elements & 3 \\
Roof-tiles & 1 \\
Mortar & 10 \\
Packing & 10 \\
Sand-lime bricks & Not applicable \\
Remainder (mainly small fractions of metal and & 6 \\
wood) & - \\
\hline \hline
\end{tabular}

TABLE 7. Costs of Waste of Fraction as Percentage of Total Waste Costs

\begin{tabular}{l|c}
\hline \hline \multicolumn{1}{c|}{ Application of construction material } & $\begin{array}{c}\text { Costs of waste } \\
(1)\end{array}$ \\
& $(2)$ \\
\hline Stone tablets & 26 \\
Piles & 13 \\
Concrete & 7 \\
Sand-lime elements & 8 \\
Roof-tiles & 13 \\
Mortar & 5 \\
Sand-lime bricks & 3 \\
\hline
\end{tabular}

aware of the relevance of other factors besides the commonsense options for waste prevention at the building site, such as variably ordering building materials and paying attention to the environmental impact of the dimensions of building materials during design.

On the basis of brainstorm sessions with eight representatives of contracting companies that were involved in the realization of the project, an inventory was made of the causes of the production of the construction waste created by the use of various building materials. Table 8 shows the results of this inventory. It appears that the majority of the technical causes are created by organizational imperfections in a building project. Other participants in the project greatly contribute to these imperfections, and it appears that the origin of the technical causes often lies in a phase of the project preceding the realization phase.

\section{Stone Tablets}

Stone tablets of clay are used for the building facings. In most cases, a wall of $1 \mathrm{~m}^{2}$ consists of 70-73 stone tablets, depending on the length and width of the stone tablet that can 
TABLE 8. Causes of Construction Waste in Considered Dutch Cases

\begin{tabular}{|c|c|c|}
\hline $\begin{array}{l}\text { Application of } \\
\text { construction } \\
\text { material } \\
\text { (1) }\end{array}$ & $\begin{array}{c}\text { Cause } \\
\text { (2) }\end{array}$ & $\begin{array}{c}\text { Specification } \\
\text { (3) }\end{array}$ \\
\hline Stone tablets & Cutting & $\begin{array}{l}\text { Lack of tuning between the sizes of } \\
\text { different products; imperfections } \\
\text { of the product; waste-causing } \\
\text { choices in design; lack of influence } \\
\text { of contractors and lack of knowl- } \\
\text { edge about building during the de- } \\
\text { sign activities }\end{array}$ \\
\hline Stone tablets & Shape & $\begin{array}{l}\text { Imperfections of product; choices } \\
\text { made in design about specifica- } \\
\text { tions of the product; method of } \\
\text { transportation }\end{array}$ \\
\hline Stone tablets & Quality & $\begin{array}{l}\text { Choice of a low-quality stone tablet } \\
\text { in design; lack of influence of con- } \\
\text { tractors and lack of knowledge } \\
\text { about building during the design } \\
\text { activities }\end{array}$ \\
\hline Stone tablets & Order too much & $\begin{array}{l}\text { Lack of possibilities to order small } \\
\text { quantities }\end{array}$ \\
\hline Stone tablets & $\begin{array}{l}\text { Storage and han- } \\
\text { dling on con- } \\
\text { struction site }\end{array}$ & Unpacked supply \\
\hline Stone tablets & $\begin{array}{c}\text { Cracking during } \\
\text { transportation }\end{array}$ & Unpacked supply \\
\hline Piles & $\begin{array}{l}\text { Cutting off the } \\
\text { top }\end{array}$ & $\begin{array}{l}\text { Method to lay the foundations of a } \\
\text { building }\end{array}$ \\
\hline Concrete & $\begin{array}{l}\text { Ordering too } \\
\text { much }\end{array}$ & $\begin{array}{l}\text { Required quantity of products un- } \\
\text { known due to imperfect planning }\end{array}$ \\
\hline Concrete & $\begin{array}{l}\text { Loss during } \\
\text { transportation }\end{array}$ & $\begin{array}{l}\text { Required quantity of products un- } \\
\text { known due to imperfect planning }\end{array}$ \\
\hline Concrete & Scraping off & $\begin{array}{l}\text { Method to lay the foundations of a } \\
\text { building }\end{array}$ \\
\hline $\begin{array}{l}\text { Sand-lime bricks } \\
\text { and elements }\end{array}$ & Cutting & $\begin{array}{l}\text { Use of products of a size that does } \\
\text { not fit }\end{array}$ \\
\hline $\begin{array}{l}\text { Sand-lime bricks } \\
\text { and elements }\end{array}$ & $\begin{array}{l}\text { Handling, stor- } \\
\text { age and at- } \\
\text { mospheric } \\
\text { influences }\end{array}$ & Unpacked supply \\
\hline Roof tiles & $\begin{array}{l}\text { Sawing conse- } \\
\text { quent on the } \\
\text { design of the } \\
\text { roof }\end{array}$ & $\begin{array}{l}\text { Attention not paid to sizes of the } \\
\text { used products in design; designer } \\
\text { not familiar with possibilities of } \\
\text { different products; information } \\
\text { about the sorts and sizes of the } \\
\text { products that will be used late; } \\
\text { types and sizes of the different } \\
\text { products do not fit }\end{array}$ \\
\hline Roof tiles & $\begin{array}{c}\text { Cracking during } \\
\text { transportation }\end{array}$ & Negligent handling by the supplier \\
\hline Mortar & Scraping out & Negligent practice \\
\hline Mortar & $\begin{array}{l}\text { Mortar in the } \\
\text { tub }\end{array}$ & Negligent practice \\
\hline Mortar & $\begin{array}{l}\text { Atmospheric } \\
\text { influences }\end{array}$ & Negligent practice \\
\hline Mortar & $\begin{array}{l}\text { Specifications of } \\
\text { the mortar }\end{array}$ & Short processing time \\
\hline Mortar & Messing & $\begin{array}{l}\text { Negligent practice; quantities of sup- } \\
\text { ply too high }\end{array}$ \\
\hline Packing & Unpacking & Throw-away packaging \\
\hline
\end{tabular}

vary in consequence of the production process. The dimensions of frequently used stone tablets are length, 208-220 $\mathrm{mm}$; width, 52-56 mm; and depth, 101-107 mm.

Factors that cannot be influenced by the contractor but affect the waste produced during the use of stone tablets are design choices, the stone tablet itself, and the way it is supplied.

Design factors involve, among other things, the type of stone and insufficient considerations of the dimensions of building materials. Piers, upright courses, sharp angles, pitched roofs, and certain types of masonry bonds create much waste at the building site, since they require stones to be cut. Factors involving the stone tablet itself are imperfections of the product, such as insufficient dimensional stability, insufficient applicability and the lack of bilateral symmetry. The supplier may play a role in the production of construction waste through unpackaged delivery, long delivery times, and the impossibility to order small quantities.

\section{Piles}

Prefab piles of concrete and wood are frequently used for the foundations of the buildings. Decapitation is the cause of the production of piling waste. This technique involves removing the part of the pile that remains above ground level after piling. Piles are made longer than necessary because the exact depth of the foundation stratum is often unknown. A foundation method using prefab piles of concrete produced a relatively large amount of waste.

\section{Concrete}

Concrete is used for the foundations of the buildings. The causes listed here mainly concern the quantity of concrete used. The building contractor may not know the necessary quantity because of imperfect planning. This leads to overordering and overfilling of the means of transport and the formwork. If the formwork is overfilled, skimming becomes necessary, i.e., leveling off the concrete poured into the formwork. This cannot be avoided when a poured concrete foundation is required.

\section{Sand-Lime Bricks and Elements}

Sand-lime bricks and elements are used for the brickwork of the buildings. The dimensions of frequently used sand-lime bricks are length, $214 \mathrm{~mm}$; width, $72 \mathrm{~mm}$; and depth, $102 \mathrm{~mm}$. The dimensions of an average sand-lime element are length, $897 \mathrm{~mm}$; width, $598 \mathrm{~mm}$; and depth, $150 \mathrm{~mm}$.

Most causes of the production of sand-lime waste resemble those mentioned in connection with stone tablets. In both cases, cutting is a factor. Unpackaged delivery means that sand-lime bricks and elements may become wet and dirty because of inclement weather and storage in the open air.

\section{Roof Tiles}

Roof tiles of clay are used for the (inclined) roofings of the buildings. The dimensions of frequently used roof tiles are 250 $\mathrm{mm}$ by $365 \mathrm{~mm}$. A roofing of $1 \mathrm{~m}^{2}$ consists of 16 overlapping roof tiles.

In the case of roof tiles, waste is mainly caused by sawing that becomes necessary when insufficient attention is paid to the dimensions of the available tiles in the design phase. The shape of the roof is also important; a pyramid roof, for example, results in much waste. The collaboration between the various participants could be improved on this point. The designer often lacks knowledge about roof tile specifications, and the contractor is often informed too late about the type and size of roof tile to be used.

Breakage during transport is also a factor. Rough handling of the tiles used in two construction projects resulted in a wastage of $15 \%$ of the amount purchased.

\section{Mortar}

Mortar is used to set stone tablets and sand-lime bricks as well as to finish off the facings of the buildings.

The main cause of waste here is the scraping out of mortar from the spaces between the facing bricks. This usually occurs before pointing, in view of the necessary durability of the walls. If the designer specifies the use of stone tablets - and 
TABLE 9. Extended Llst of Sources and Causes of Construction Waste (based on Tables 4 and 8)

\begin{tabular}{|c|c|}
\hline $\begin{array}{l}\text { Source } \\
\text { (1) }\end{array}$ & $\begin{array}{c}\text { Cause } \\
\text { (2) }\end{array}$ \\
\hline Design & Error in contract documents \\
\hline Design & $\begin{array}{l}\text { Contract documents incomplete at commencement of } \\
\text { construction }\end{array}$ \\
\hline Design & Changes to design \\
\hline Design & Choices about specifications of products \\
\hline Design & Choice of low quality products \\
\hline Design & Lack of attention paid to sizes of used products \\
\hline Design & $\begin{array}{l}\text { Designer is not familiar with possibilities of different } \\
\text { products }\end{array}$ \\
\hline Design & $\begin{array}{l}\text { Lack of influence of contractors and lack of knowl- } \\
\text { edge about construction }\end{array}$ \\
\hline Procurement & $\begin{array}{l}\text { Ordering error, overordering, underordering, and so } \\
\text { on }\end{array}$ \\
\hline Procurement & Lack of possibilities to order small quantities \\
\hline Procurement & Use of products that do not fit \\
\hline Materials handling & Damaged during transportation to site/on site \\
\hline Materials handling & $\begin{array}{l}\text { Inappropriate storage leading to damage or deter- } \\
\text { iorization }\end{array}$ \\
\hline Materials handling & Unpacked supply \\
\hline Materials handling & Throwaway packaging \\
\hline Operation & Error by tradesperson or laborer \\
\hline Operation & Equipment malfunction \\
\hline Operation & Inclement weather \\
\hline Operation & Accidents \\
\hline Operation & Damage caused by subsequent trades \\
\hline Operation & Use of incorrect material, requiring replacement \\
\hline Operation & Method to lay the foundation \\
\hline Operation & $\begin{array}{l}\text { Required quantity of products unknown due to im- } \\
\text { perfect planning }\end{array}$ \\
\hline Operation & $\begin{array}{l}\text { Information about types and sizes of products that } \\
\text { will be used arrives too late at the contractor }\end{array}$ \\
\hline Residual & Conversion waste from cutting uneconomical shapes \\
\hline Residual & Offcuts from cutting materials to length \\
\hline Residual & $\begin{array}{l}\text { Overmixing of materials for wet trades due to a lack } \\
\text { of knowledge of requirements }\end{array}$ \\
\hline Residual & Waste from application process \\
\hline Residual & Packaging \\
\hline Other & Criminal waste due to damage or theft \\
\hline Other & $\begin{array}{l}\text { Lack of on site materials control and waste manage- } \\
\text { ment plans }\end{array}$ \\
\hline
\end{tabular}

pointing thus becomes necessary - scraping out mortar cannot be avoided. Other causes of waste are mixing too much mortar and spills during its transport around the building site.

Too much mortar being mixed creates residues in tubs, wheelbarrows, and mixers. The supplier is partly to blame, as contractors are usually faced with a minimum-order obligation and therefore usually receive too much mortar.

\section{Packaging}

The cause of the production of packaging waste is the supply of building materials in disposable packaging materials.

In Table 9 the known causes (Table 4) and newly recognized causes (Table 8) are integrated. The list shows that a great amount of the causes of the generation of construction waste can be related to both design activities and operation activities.

\section{CONCLUSIONS}

Integrated chain management is one of three policy areas of The Dutch National Environmental Policy Plans. For the building and construction industry this policy area implies, among other things, prevention of construction waste.

In The Netherlands, for five residential-building projects and for a large number of construction materials, the amount of construction waste has been quantified. The research project indicates that the main amount of solid waste in a construction project is caused by the use of a small variety of construction materials. Eighty percent of construction waste was caused by the use of stone tablets, piles, concrete, sand-lime elements, and roof tiles (Table 5). This caused $67 \%$ of the total waste costs (Table 7).

The research data indicate that $9 \%$ of the totally purchased materials end up as waste (by weight). From $1 \%$ to $10 \%$ of every single purchased construction material leaves the construction site as solid waste (Table 6). Though this amount is still substantial and should be reduced further, it is well below the waste generated in comparable projects in Brazil. The presented literature survey shows that in Brazil, 20-30\% of the purchased materials are not used well and end up as waste.

A thorough source evaluation of the generated Dutch waste reveals new sources and causes in addition to those already reported in the literature. This information has been gathered in a new and extended list of sources and causes. This list shows that a great amount of the causes of the generation of construction waste can be related to both design activities and operation activities.

\section{APPENDIX. REFERENCES}

Apotheker, S. (1990). "Construction and demolition debris - The invisible waste stream." Resour. Recycling, 9(12) 66-74.

Bossink, B. A. G. (1994). Bouwafial op de bouwplaats: hoeveelheden, oorzaken en preventie opties, Enschede, Univ. of Twente, The Netherlands (in Dutch).

Brooks, K. A., Adams, C., and Demsetz, L. A. (1994). “Germany's construction and demolition debris recycling infrastructure: What lessons does it have for the U.S.?" Sustainable construction (Proc. Ist Conf. of CIB TG 16), C. J. Kibert, ed., 647-656.

Brundtland, G. H. (1987). Our common future. World Commission on Envir. and Devel.

Buchner, S., and Scholten, L. J. (1992). Demolition and construction debris. Questionnaire about an EC priority waste stream. European Demolition Assoc., The Hague, The Netherlands.

Craven, D. J., Okraglik, H. M., and Eilenberg, I. M. (1994). “Construction waste and a new design methodology." Sustainable construction (Proc. Ist Conf. of CIB TG 16), C. J. Kibert, ed., Ctr. for Constr. and Envir., Gainesville, Fla., 89-98.

de Pauw, C., Vyncke, J., and Desmyter, J. (1994). "'Reuse of demolition waste as aggregates in concrete. A new challenge or the re-introduction of old practise?' Sustainable construction (Proc. 1st Conf. of CIB TG 16), C. J. Kibert, ed., Ctr. for Constr. and Envir., Gainesville, Fla., 385-394.

The Dutch national environmental policy plan. (1989). Ministry of Housing, Town and Country Plng. and Envir. (VROM), SDU, Den Haag, The Netherlands.

The Dutch national environmental policy plan +. (1990). Ministry of Housing, Town, and Country Plng. and Envir. (VROM), SDU, Den Haag, The Netherlands (in Dutch).

The Dutch national environmental policy plan 2. (1993). Ministry of Housing, Town, and Country Plng. and Envir. (VROM), SDU, Den Haag, The Netherlands (in Dutch).

Formoso, C. T., et al. (1993). "Developing a method for controlling material waste on building sites." Economic evaluation and the built environment, CIB, Lisbon, Portugal.

Gavilan, R. M., and Bernold, L. E. (1994). "Source evaluation of solid waste in building construction." J. Constr. Engrg. and Mgmt., ASCE, $120(3), 536-555$.

Hamassaki, L. T., and Neto, C. S. (1994). "Technical and economic aspects of construction/demolition waste utilization." Sustainable construction (Proc. 1st Conf. of CIB TG 16), C. J. Kibert, ed., Ctr. for Constr. and Envir., Gainesville, Fla., 395-403.

Hanisch, J., et al. (1991). "Aspects of processing techniques for recycling of bulk material." Mineral Processing, 32(1), 10-17.

Heino, E. (1994). "Recycling of construction waste." Sustainable construction (Proc. 1st Conf. of CIB TG 16), C. J. Kibert, ed., Ctr. for Constr. and Envir., Gainesville, Fla., 565-572.

Implementatieplan Bouw- en sloopafial. (1993). Ministry of Housing, Town, and Country Plng. and Envir. (VROM), Distributiecentrum VROM, Zoetermeer, The Netherlands (in Dutch).

Kohler, G., and Kircher, R. (1993). "Anlagenkonzepte zur Herstellung hochwertiger Recycling-produkte." Baustoff Recycling, 94/95, 93116.

Lanting, R. W. (1993). "Stofstromen in de bouw en het milieubeleid." 
Ketenbeheer in de bouw, T. J. J. B. Wolters, ed., Samsom Bedrijfsinformatie, Alphen aan den Rijn, The Netherlands, 25-38 (in Dutch).

Mincks, W. R. (1994). "The construction contractor's waste management plan: optimizing control and cost." Sustainable construction (Proc. 1st Conf. CIB TG 16), C. J. Kibert, ed., Ctr. for Constr. and Envir., Gainesville, Fla., 765-774.

Ottens, E. (1994). "Op naar 0!; Preventie van bouwafval in bouwproces en materialenketen," MS thesis, University of Twente, Enschede, The Netherlands.

Peng, C.-L., Grosskopf, K. R., and Kibert, C. J. (1994). "Construction waste management and recycling strategies in the United States." Sustainable construction (Proc. Ist Conf. of CIB TG 16), C. J. Kibert, ed. Ctr. for Constr. and Envir., Gainesville, Fla., 689-696.

Pinto, T. P. (1989). Perda de materiais em processos construtivos tradicionais. UFSCAR Departamento de Engenharia Civil, Sao Carlos, Brazil.
Pinto, T. P., and Agopayan, V. (1994). "Construction wastes as raw materials for low-cost construction products." Sustainable construction (Proc. 1st Conf. of CIB TG 16), C. J. Kibert, ed., Ctr. for Constr. and Envir., Gainesville, Fla., 335-342.

Preventie van afvalstoffen, emissies en energieverbruik in de bouwnijverheid. (1994). Provincie Overijssel, NVOB Gewest Overijssel/Flevoland, and Heidemij advies, Zwolle, The Netherlands.

Rogoff, M. J., and Williams, J. F. (1994). Approaches to implementing solid waste recycling facilities. Noyes Publications, Park Ridge, N.J.

Ruch, M., and Rentz, O. (1994). "Demolition waste management strategies in France and Germany." Sustainable construction (Proc. Ist Conf. of CIB TG 16). C. J. Kibert, ed., Ctr. for Constr. and Envir. Gainesville, Fla., 363-372.

Soibelman, L., Formoso, C. T., and Franchi, C. C. (1994). "A study on the waste of materials in the building industry in Brazil." Sustainable construction (Proc. 1st Conf. of CIB TG 16), C. J. Kibert, ed., Ctr. for Constr. and Envir., Gainesville, Fla., 555-563. 